\title{
Article \\ Genome-Wide Identification of GDSL-Type Esterase/Lipase Gene Family in Dasypyrum villosum L. Reveals that DvGELP53 Is Related to BSMV Infection
}

\author{
Heng Zhang ${ }^{1,2,+}$, Xu Zhang ${ }^{2,+}$, Jia Zhao ${ }^{3}$, Li Sun ${ }^{2}$, Haiyan Wang ${ }^{2}$, Ying Zhu ${ }^{1}$, Jin Xiao ${ }^{2}$ and Xiue Wang ${ }^{2, *(1)}$ \\ 1 State Key Laboratory for Managing Biotic and Chemical Threats to The Quality and Safety of Agro-Products, \\ Institute of Virology and Biotechnology, Zhejiang Academy of Agricultural Sciences, Hangzhou 310021, \\ China; zhangheng20170927@163.com (H.Z.); yzhuzaas@163.com (Y.Z.) \\ 2 State Key Lab of Crop Genetics and Germplasm Enhancement, Cytogenetics Institute, Nanjing Agricultural \\ University/JCIC-MCP, Nanjing 210095, China; 2018201061@njau.edu.cn (X.Z.); sunli@njau.edu.cn (L.S.); \\ hywang@njau.edu.cn (H.W.); xiaojin@njau.edu.cn (J.X.) \\ 3 College of Agriculture, South China Agriculture University, Guangzhou 510642, China; zhaojia@scau.edu.cn \\ * Correspondence: xiuew@njau.edu.cn; Tel.: +86-25-84395308 \\ + The two authors contributed equally to this work.
}

check for updates

Citation: Zhang, H.; Zhang, X.; Zhao, J.; Sun, L.; Wang, H.; Zhu, Y.; Xiao, J.; Wang, X. Genome-Wide Identification of GDSL-Type Esterase/Lipase Gene Family in Dasypyrum villosum L. Reveals that DvGELP53 Is Related to BSMV Infection. Int. J. Mol. Sci. 2021, 22, 12317. https://doi.org/10.3390/ ijms222212317

Academic Editor: Kenji Miura

Received: 26 October 2021

Accepted: 11 November 2021

Published: 15 November 2021

Publisher's Note: MDPI stays neutral with regard to jurisdictional claims in published maps and institutional affiliations.

Copyright: (c) 2021 by the authors. Licensee MDPI, Basel, Switzerland. This article is an open access article distributed under the terms and conditions of the Creative Commons Attribution (CC BY) license (https:// creativecommons.org/licenses/by/ $4.0 /)$.

\begin{abstract}
GDSL-type esterase/lipase proteins (GELPs) characterized by a conserved GDSL motif at their N-terminus belong to the lipid hydrolysis enzyme superfamily. In plants, GELPs play an important role in plant growth, development and stress response. The studies of the identification and characterization of the GELP gene family in Triticeae have not been reported. In this study, 193 DvGELPs were identified in Dasypyrum villosum and classified into 11 groups (clade A-K) by means of phylogenetic analysis. Most DvGELPs contain only one GDSL domain, only four DvGELPS contain other domains besides the GDSL domain. Gene structure analysis indicated $35.2 \%$ DvGELP genes have four introns and five exons. In the promoter regions of the identified DvGELPS, we detected 4502 putative cis-elements, which were associated with plant hormones, plant growth, environmental stress and light responsiveness. Expression profiling revealed 36, 44 and 17 DvGELPS were highly expressed in the spike, the root and the grain, respectively. Further investigation of a root-specific expressing GELP, DvGELP53, indicated it was induced by a variety of biotic and abiotic stresses. The knockdown of DvGELP53 inhibited long-distance movement of BSMV in the tissue of $D$. villosum. This research provides a genome-wide glimpse of the D. villosum GELP genes and hints at the participation of DvGELP53 in the interaction between virus and plants.
\end{abstract}

Keywords: GELP; gene family; Dasypyrum villosum L.; virus movement

\section{Introduction}

The GDSL-type esterase/lipase protein (GELP, esterase, EC 3.1.1) is a newly discovered lipid hydrolysis enzyme (lipolytic enzyme). They are featured in having a conserved GDSL motif at the N-terminus, whereas many other lipases have the GxSxG motif near their protein center [1,2]. GELPs have a consensus sequence that is divided into five conserved sequence blocks (I-V) and four invariant important catalytic residues serine (Ser), glycine (Gly), asparagine (Asn) and histidine (His) in blocks I, II, III and V, respectively [1]. The active-site Ser in block I and the Asp, His residues in block V compose a catalytic triad existing in all GELPs. The Gly residue in block II and the Asn in block III act as proton donors to the oxyanion hole [1,2]. GDSL lipases were widely found in prokaryotes and eukaryotes [3]. To date, GELP family genes have been well-studied at the genome-wide level in various species. A total of 105, 114,194, 114, 96, 126 and 130 GELP genes have been identified in Arabidopsis thaliana, Oryza sativa, soybean, Brassica rapa, Vitis vinifera, Populus trichocarpa and Sorghum bicolor, respectively [3-6]. 
The functions of GELPs have been extensively studied in Arabidopsis [7], Oryza [8], pepper [9] and other plants. They are mainly involved in the regulation of plant development, morphogenesis, synthesis of secondary metabolites and defense response. AtEXL4 from Arabidopsis [10], ZmMS30 from maize [11], OsGELP34, OsGELP110 and OsGELP115 from rice [12] were proven to regulate the pollen development. Arabidopsis GDSL-type esterase gene AtSFAR4 (seed fatty acid reducers) is intensely expressed in embryo protrusion, early seedlings and pollen and plays a role in enhancing the seed germination rate through upregulating fatty acid degradation-related genes [13]. The BS1 from Oryza encoding a GDSL lipase plays an important role in the maintenance of proper acetylation level on the xylan backbone, which is crucial for secondary wall formation and patterning [14]. As a sinapine esterase involved in secondary metabolism, GDSL lipase-like genes, such as BnSCE3/BnLIP2 in Brassicaceae, catalyze hydrolysis of sinapine during seed germination [15]. More and more evidence is accumulated for the critical role of GELP in biotic stress response through hormone signaling regulation. In Arabidopsis, GLIP1 modulates resistance of multiple pathogens by manipulating ethylene (ET) signaling $[16,17]$. The pepper CaGLIP1 expression was induced by salicylic acid (SA), ET, methyl jasmonate (MeJA) and abiotic stress. Knockdown of CaGLIP1 in pepper conferred enhanced resistance to Xcv (Xanthomonas campestris pv. vesicatoria), while overexpression of CaGLIP1 in Arabidopsis compromised the resistance to the bacterial pathogen Pseudomonas syringae pv. tomato [9]. In rice, OsGLIP1 and OsGLIP2 were suppressed by pathogen infection and SA treatment. Increased expression of OsGLIP1 and OsGLIP2 compromised the disease resistance in rice, while knocking them down elevated the resistance to bacterial and fungal pathogens [8]. Moreover, OsGLIP2 contributed resistance to Erwinia carotovora via negatively regulating auxin signaling [18]. Besides, recent studies have shown that GELPS are also involved in abiotic stress response in plants. For example, overexpression of AtSFAR4 enhanced the osmosis tolerance to glucose [13]. Transgenic Arabidopsis overexpressing AtLTL1, which was rapidly induced by $\mathrm{LiCl}$ and $\mathrm{NaCl}$, elevated the salt tolerance [7]. The CaGLIP1 transgenic pepper showed drought tolerance during seed germination and the plant growth stage [9]. All these results indicated that GELPs are important enzymes in plants and may have multiple functions in regulating various physiological processes.

Viruses can cause diseases in a variety of crops and reduce their yield and quality, such as in wheat, barley and rice [19]. After invasion, viruses rapidly spread to the whole plant and cause disease symptoms. The virus movement in plants is generally divided into two aspects: cell-to-cell through plasmodesmata and long-distance through the phloem [20]. Genes related to virus movement have been identified both in plants and viruses. In viruses, the $37 \mathrm{kD}$ MP (movement proteins) from SBWMV (Soil-borne wheat mosaic virus) and CI (cylindrical inclusion) from WYMV (Wheat yellow mosaic virus) were shown to mediate the cell-to-cell and long-distance virus movement [21-23]. P3N-PIPO and VPg (viral genome-linked protein) from several potyvirus species have been proven to participate in virus movement as well [24-26]. However, only a few plant proteins have been identified to be involved in virus movement. For example, NbHIPP26 from Nicotiana benthamiana ( $N$. benthamiana) interacted with the movement protein TGB1 from potato mop-top virus to facilitate long-distance virus movement [27]. The interaction between VPg and PVIP (Potyvirus VPg-interaction protein) may modulate expression of host genes involved in virus movement [28,29]. To better understand the plant-virus interaction and the molecular mechanism of plant defense against the virus, more genes related to virus movement should be identified in plants.

Common wheat (Triticum aestivum L. AABBDD, $2 n=6 x=42$ ) is a hexaploid with a huge and complex genome [30-32]. This causes difficulties in the analysis of gene families and functions. Dasypyrum villosum L. (D. villosum, $2 n=2 x=14, \mathrm{VV})$, also known as Haynaldia villosa, is a diploid wild relative of wheat [33]. D. villosum possesses high resistance or tolerance to abiotic and biotic stresses, such as powdery mildew [34,35], yellow rust [36], WYMV [37] salt [38] and so on. It is an excellent genetic resource for wheat improvement. The purpose of this study was as follows: understand the evolution 
and function of the GELP family genes in D. villosum and discover the genes regulating virus resistance. We performed genome-wide identification of GELP in D. villosum. The evolutionary relationship, chromosome distribution and protein structure of GELPs were further analyzed in D. villosum. DvGELP53, a GELP specifically expressed in the root, was chosen for further characterization to elucidate its function in response to virus infection using a barley stripe mosaic virus (BSMV)-induced gene silencing system. Our results will facilitate the understanding of the evolution, diversification and function of GELPs in D. villosum.

\section{Results}

2.1. Genome-Wide Identification of the GELP Gene Family in D. villosum

A total of 193 GELP family genes were identified in the genome of $D$. villosum; they were designated DvGELP1-DvGELP193 according to their chromosomal locations (Table S1). DvGELP83 has the shortest CDS of $717 \mathrm{bp}$ and encodes a protein of 238 amino acids (aa), while DvGELP60 has the longest CDS of 2742 bp and encodes a 913 aa protein. A phylogenetical neighbor-joining tree of DvGELPS was built; DvGELPS could be divided into 11 clades. Clades A-K had 22, 13, 8, 30, 11, 26, 34, 19, 23, 2, 4 DvGELPs, respectively. Clade $\mathrm{J}$ was the smallest clade and had only two members while Clade $G$ was the largest and had 34 members (Figure 1). The numbers of DvGELPs were quite different across clades, implying the functional divergence of these genes.

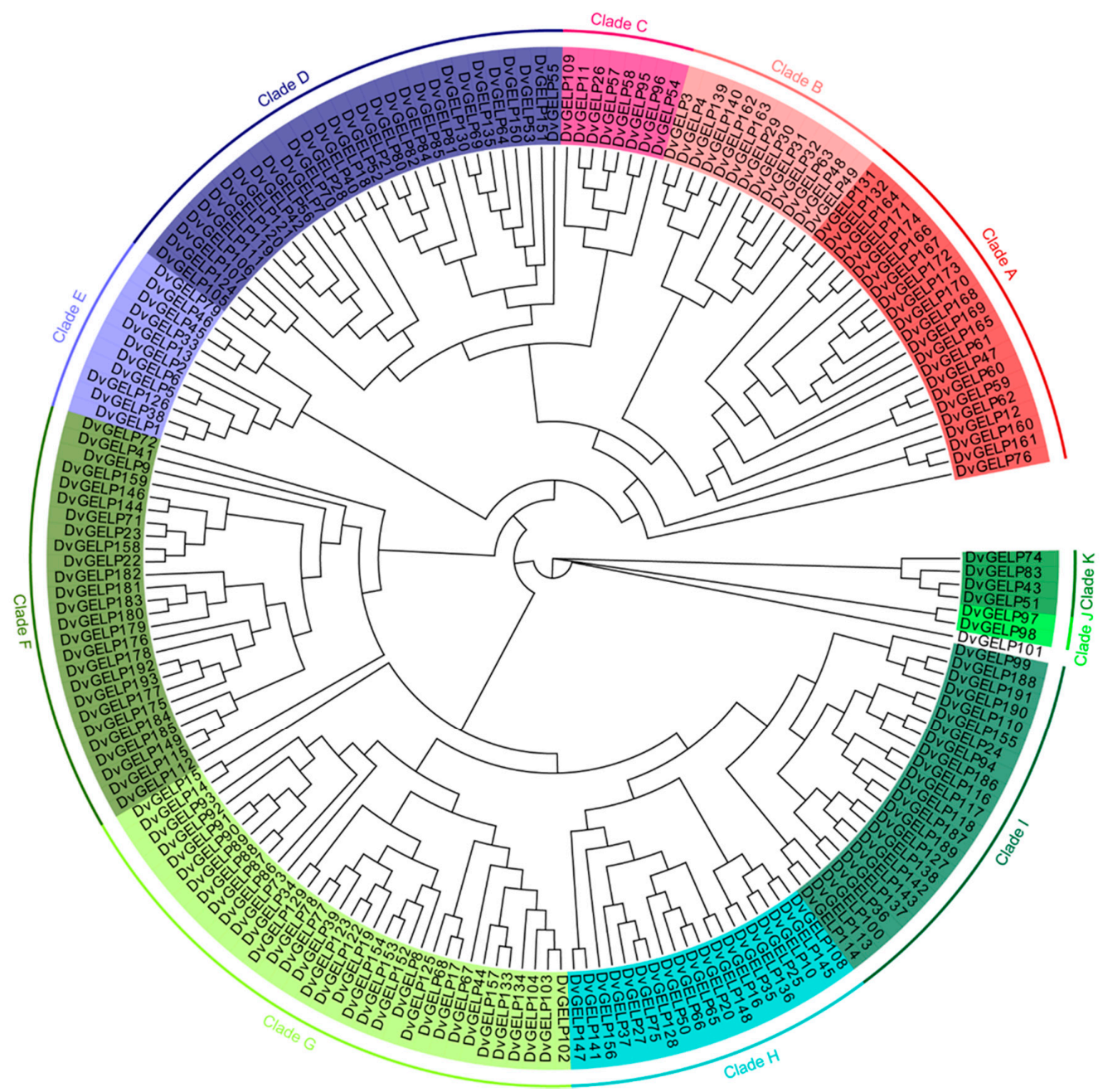

Figure 1. The phylogenetic tree of the GELP gene family from D. villosum. 
DvGELPs were analyzed for their conserved domains using the Conserved Domain Database. All the predicted DvGELPs had one lipase GDSL domain, and only four DvGELPs had other functional domains. DvGELP36 and DvGELP188 had an SGNH_hydrolase superfamily domain, DvGELP37 had an ATP-synt_Z domain, and DvGELP52 had a Glyco_hydro superfamily and X8 domain (Figure S1).

The exon-intron structure of the DvGELPs belonging to different subgroups was analyzed and compared (Figure S1). Three DvGELPS (DvGELP19, DvGELP50 and DvGELP83) had no introns, and the number of introns of the remaining genes ranged from one to 14. DvGELPs with four introns are the most common in this gene family (68 out of 193, $35.2 \%$ ), followed by those having three and two introns, which account for $15.0 \%$ (29 out of 193) and 20.2\% (39 out of 193), respectively. DvGELPS containing eight, ten and 14 introns account for $1.0 \%, 1.0 \%$ and $0.5 \%$, respectively (Table S1). These results are consistent with the previous rule that GELPS with four introns are the majority in plants. For example, the members of GELP with four introns were approximately $67.6 \%, 49.1 \%$ and $74.2 \%$ in Arabidopsis, rice and soybean, respectively. The number of introns of DvGELPS within a closer phylogenetic relationship is generally similar, but exceptions were also observed for some genes. For instance, DvGELP21 and DvGELP80 belong to the same branch of Class D; the former has seven introns while the latter has two introns (Figure S1). The difference in gene structure may reveal the evolutionary and functional differentiation of DvGELP genes across different subgroups as well as within the same subgroup.

\subsection{Chromosomal Location of DvGELPS}

The chromosomal location analysis revealed the DvGELPS were distributed on all the seven chromosomes and two scaffolds of the D. villosum genome (D. villosum sequence was accomplished but not released). The number of DvGELP genes on different chromosomes varied. There were 24, 18, 29, 27, 20, 28 and 45 DvGELPS in the chromosomes 1-7V, respectively. Chromosome $7 \mathrm{~V}$ had the most $(23.3 \%)$ and $2 \mathrm{~V}$ had the least DvGELPS (9.3\%). DvGELPS were mainly located in the distal region of chromosome arms, and only a few genes were in the middle of the chromosomes $1 \mathrm{~V}$ and $5 \mathrm{~V}$ (Figure 2). This result is similar to that in soybeans in that $78 \%$ of the predicted genes are located at the distal end of each chromosomal end. We also found that DvGELPS were mostly present as clusters, such as DvGELP12-24 in chromosome 1V, DvGELP76-98 in 4V and DvGELP148-191 in 7V. We speculate that this phenomenon may be caused by gene duplication during evolution.

\subsection{Promoter Sequence Analysis and Expression Profiles of DvGELPS}

The cis-elements in the promoter region play important roles in regulating gene transcription when challenged by biotic and abiotic stresses [6]. The $2.0 \mathrm{~kb}$ upstream sequence from the translational start site of DvGELPS was downloaded and analyzed using PlantCARE. A total of 4502 cis-elements were detected in the promoter region of the 193 DvGELP genes. These cis-elements included plant hormones, plant growth, environmental stress and light-responsive elements (Figure 3a). The hormone-related ciselements were the most common $(1710,38.0 \%)$, in which 130 were auxin (IAA)-responsive, 118 were gibberellin (GA)-responsive, 72 were SA-responsive, 576 were abscisic acid (ABA)-responsive and 814 were MeJA-responsive elements (Figure 3b), followed by 1517 $(33.7 \%)$ light-responsive elements (Figure 3a). In the 484 (10.8\%) environmental stress elements, three were wound-responsive, 47 were defense- and stress-responsive, 120 were low temperature-responsive and 314 were anaerobic induction elements (Figure 3c). Plant growth-related cis-elements had the least number of $341(7.6 \%)$, in which eight were cell cycle regulation, 31 were circadian control, 24 were endosperm expression, 114 were meristem expression, 67 were seed-specific regulation and four were root-specific regulation elements (Figure 3d). These results reveal that the promoter of DvGELP genes may be involved in plant growth, development and interaction with various environmental stresses, further suggesting the functional diversity of the DvGELP gene family. 


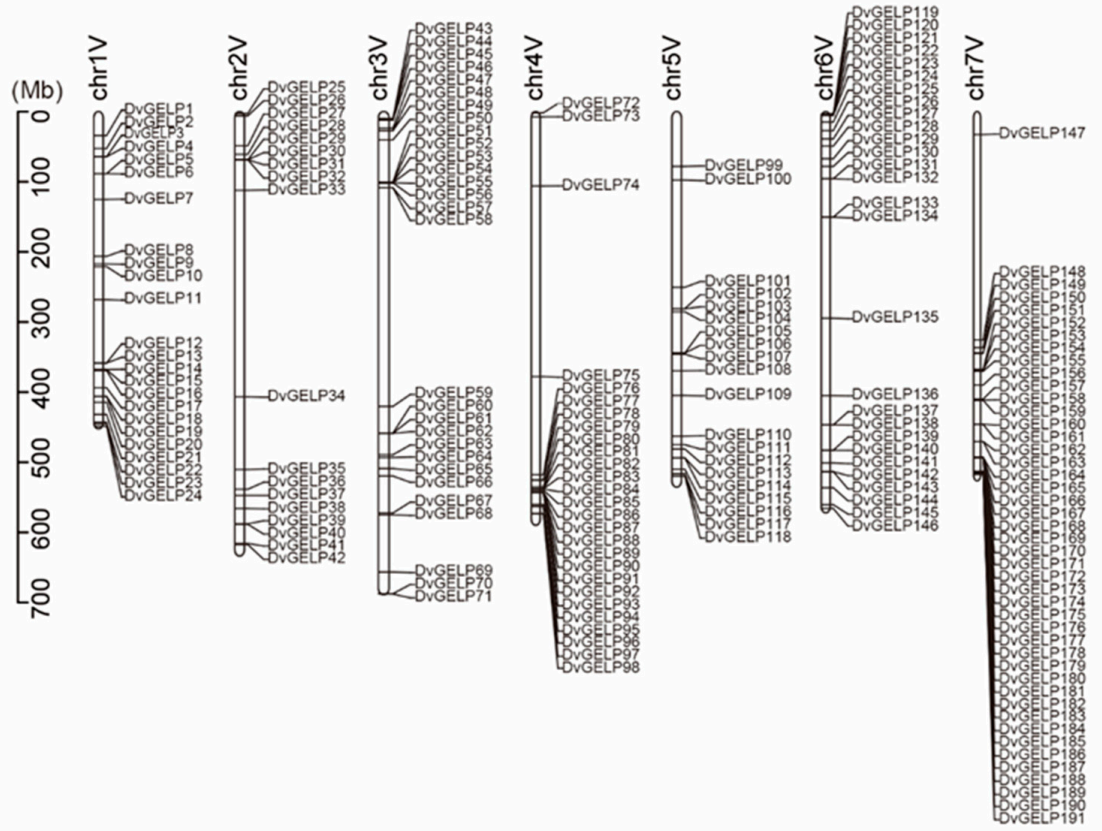

Figure 2. Chromosomal location of DvGELPs in D. villosum. The identities of the chromosome are indicated at the top of each chromosome, while the GELP gene names are shown to the right of each chromosome.

(a)

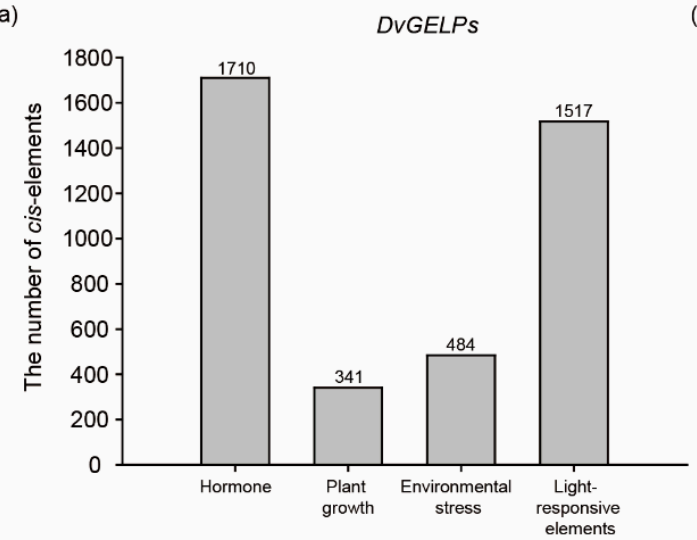

(c)

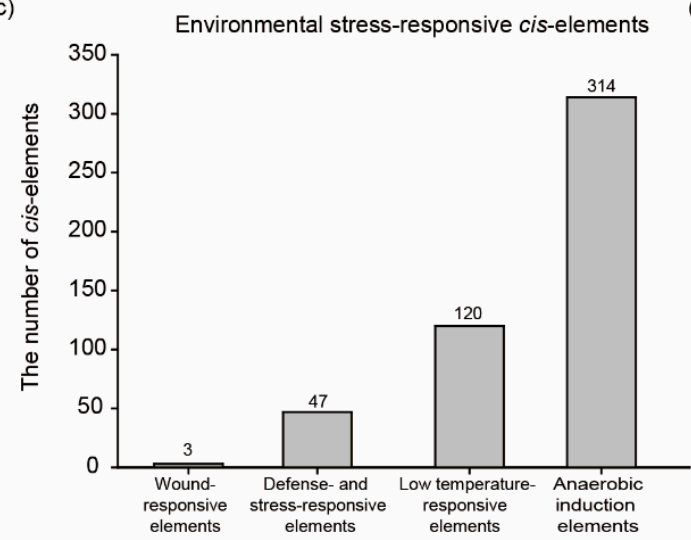

(b)

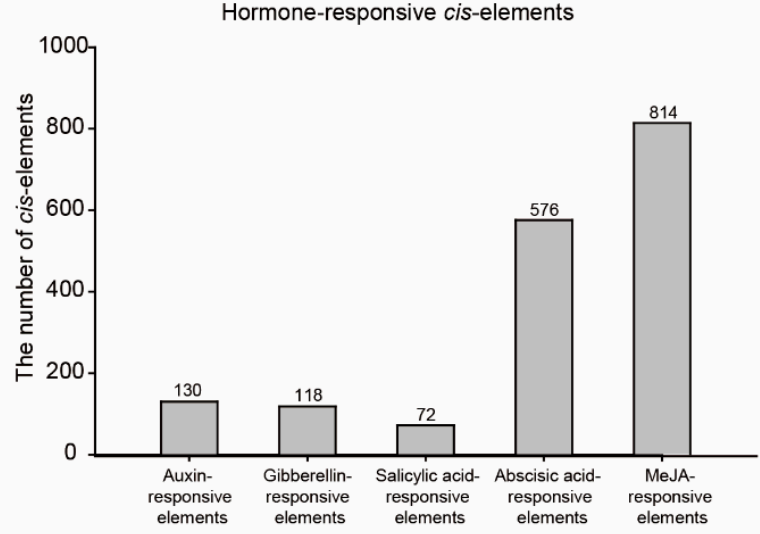

(d)

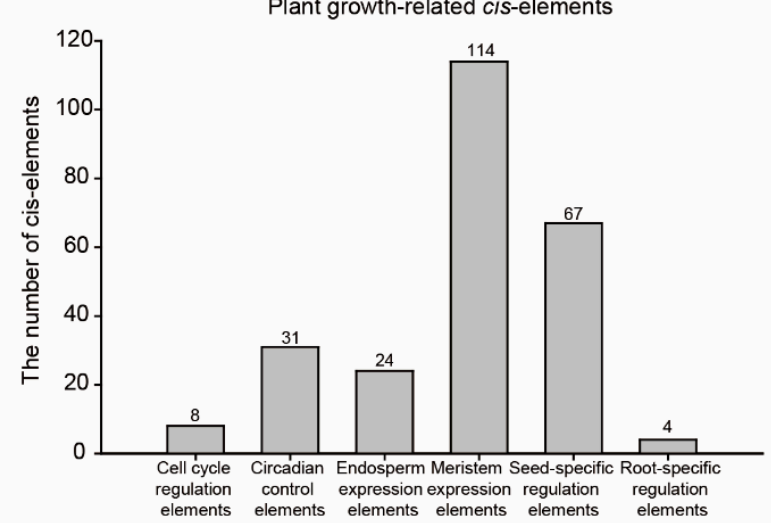

Figure 3. The cis-elements analysis of the DvGELPs promoter sequence. (a) The total number of the four types of elements. (b) The classification and number of hormone-responsive elements. (c) The classification and number of environmental stress-responsive elements. (d) The classification and number of plant growth-related elements. 
The expression pattern of different gene members may provide clues of their conserved or diversified biological function. To preliminarily predict the function of DvGELPs, we investigated their expression in different $D$. villosum tissues by RNA-seq. The results showed that 36 DvGELPs were highly transcripted in the spike (e.g., DvGELP152), 44 -in the root (e.g., DvGELP27), six-in the leaf (e.g., DvGELP85), 17-in the grain (e.g., DvGELP83), seven-in the stem (e.g., DvGELP47), 12-in the tiller bud (e.g., DvGELP33) and seven -in the node (e.g., DvGELP7) (Figure 4). A small portion of genes was highly expressed in two tissues. DvGELP138 was highly expressed both in the root and the bud, and DvGELP72 was highly expressed both in the spike and the leaf (Figure 4). A few genes were constitutionally expressed in D. villosum. For instance, DvGELP99 and DvGELP135 exhibited high transcription levels in most tissues (Figure 4). The expression of 35 genes $(18.1 \%)$ could not be detected in any tissue (i.e., DvGELP22) (Figure 4), indicating that they may not be expressed in the examined tissue or their expression may be inducible by environmental factors.
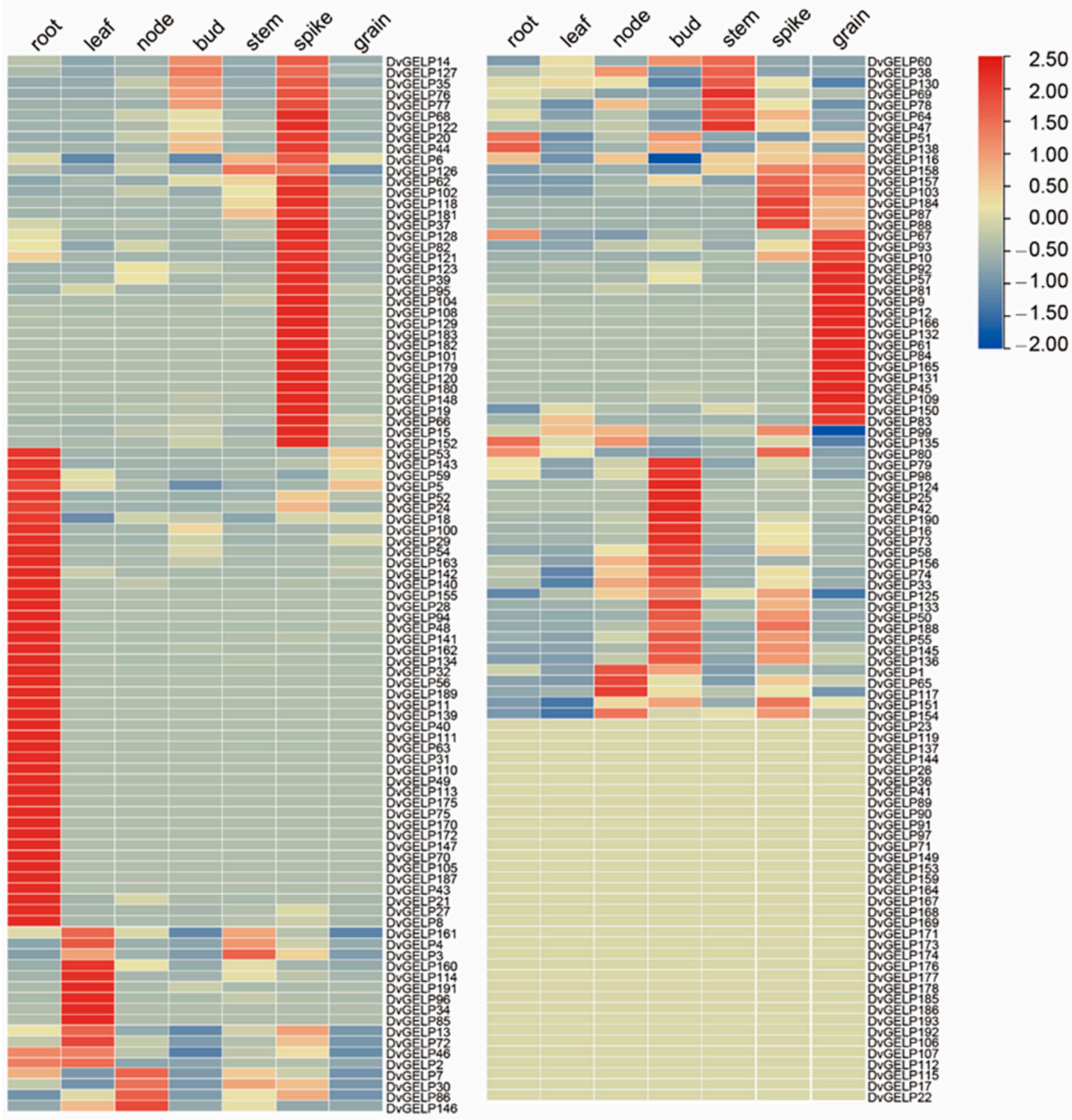

Figure 4. Heatmap of the expression profiling of D. villosum GELPs in different tissues. The expression signal of each gene was based on the Z-score normalization value from the RNA-seq data. The root, leaf, node, bud, stem and spike were sampled at $20 \mathrm{~d}$ after flowering, and the grain was sampled at the maturity stage of D. villosum. Each sample has three biological replicates. RNA-Seq was performed using a BGISEQ-500 sequencing platform by BGI Company, Shenzhen, China. 


\subsection{DvGELP53 Plays Role in Long-Distance BSMV Movement in D. villosum}

From the above results, we found that the promoter sequence of DvGELP53 included plant hormones and plant growth elements, such as MeJA-responsive, ABA-responsive and meristem expression-related elements. The expression profiling of DvGELPS showed DvGELP53 is specifically and highly expressed in roots. Previous studies reported that root-specific expression genes may be involved in plant-virus interaction [27]. We further investigated the role of DvGELP53 in response to virus infection.

DvGELP53 belongs to Clade D encoding for $1212 \mathrm{bp}$ nucleotide and 403 amino acids which contains an SGNH/GDSL hydrolase domain $\left(\mathrm{A}^{38}\right.$ to $\left.\mathrm{P}^{369}\right)$. The protein has a predicted molecular weight of $44.14 \mathrm{kD}$ and isoelectric point of 8.16. DVGELP53 was subcellularly localized to the plasma membrane and in the nucleus in the epidermal cells of N. benthamiana (Figure 5b), confirmed by the signal overlapping of GFP-DvGELP53 and plasma membrane marker protein mCherry-SYP122 (Figure 5b).

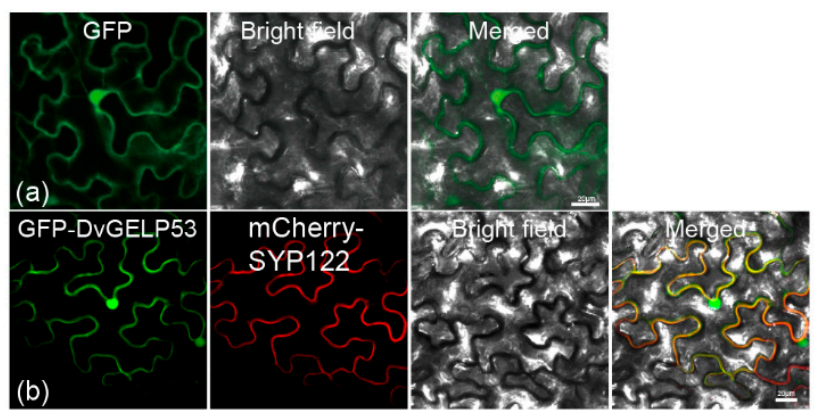

Figure 5. Subcellular localization of DvGELP53 in the epidermal cells of N. benthamiana. (a) GFP and (b) GFP-DvGELP53; GFP was used as the control. The localization of mCherry-SYP122 is shown in red, and the localization of GFP and its fusion proteins is shown in green. Scale bar $=20 \mu \mathrm{m}$.

The expression profiling of DvGELP53 was further validated by qRT-PCR. The tissuespecific expression pattern of DvGELP53 in D. villosum was confirmed, shown by that it had the highest transcription level in the root, followed by that in the leaf and a very low level in the stem (Figure 6a). In the D. villosum leaf, DVGELP53 was downregulated at 2 and $12 \mathrm{~h}$ after inoculation (hai) of Blumeria graminearum f. sp. tritici (Bgt), upregulated from 24 hai and reached a peak at 72 hai (Figure 6b). DVGELP53 was quickly accumulated when treated by means of two pathogen-associated molecular patterns (PAMP), fungal chitin and bacterial flg22 treatment. Its expression reached a peak at 2 and $72 \mathrm{~h}$ after treatment, respectively (Figure $6 c, d$ ). These indicated that DvGELP53 may be involved in the response of wheat to biotic stresses. DVGELP53 expression in the D. villosum leaf was also induced by exogenous application of phytohormones such as SA $(5 \mathrm{mM}), \mathrm{ABA}$ $(0.2 \mathrm{mM})$, ET $(0.1 \mathrm{mM})$ and $\mathrm{H}_{2} \mathrm{O}_{2}(7 \mathrm{mM})$ as well as abiotic stresses such as heavy metal cadmium $(\mathrm{Cd}, 1 \mathrm{mM})$, heat $\left(42^{\circ} \mathrm{C}\right)$, cold $\left(4^{\circ} \mathrm{C}\right)$ and salt $(\mathrm{NaCl}, 100 \mathrm{mM})$ (Figure 6e- 1$)$. These indicated that DvGELP53 participates in the regulation of phytohormone pathways and abiotic stress responses. 

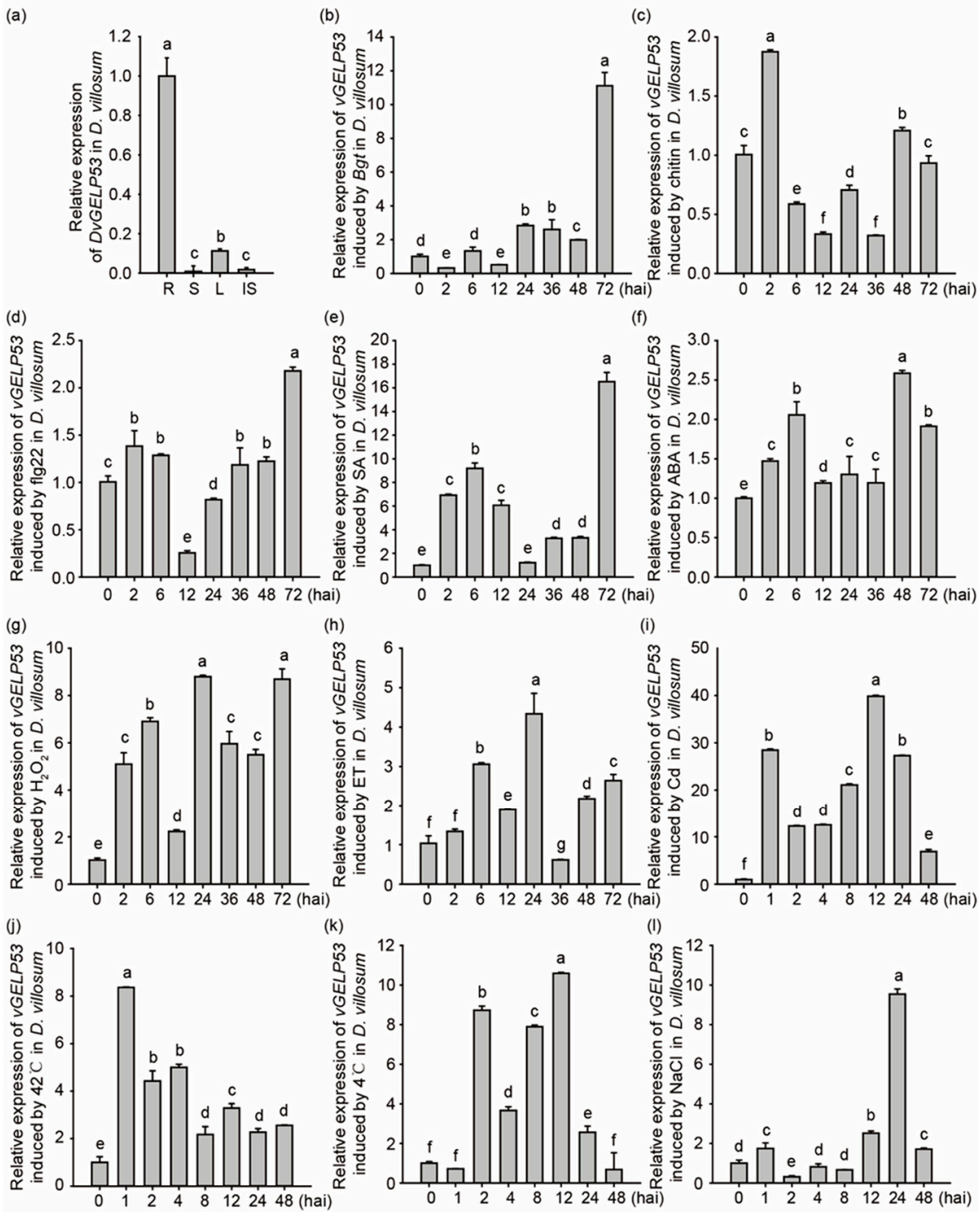

Figure 6. Expression profiling of DvGELP53. (a) The expression of DvGELP53 in the root (R), the stem (S), the leaf (L) and the immature spike (IS) of D. villosum. The expression in the root is set to 1 . Time course expression profiling of DvGELP53 in the leaf of D. villosum in response to Bgt (b), chitin (c), flg22 (d), $\mathrm{SA}(\mathbf{e}), \mathrm{ABA}(\mathbf{f}), \mathrm{H}_{2} \mathrm{O}_{2}(\mathbf{g}), \mathrm{ET}(\mathbf{h}), \mathrm{Cd}(\mathbf{i}), 42{ }^{\circ} \mathrm{C}(\mathbf{j}), 4{ }^{\circ} \mathrm{C}(\mathbf{k})$ and $\mathrm{NaCl}(\mathbf{l})$. The expression at $0 \mathrm{~h}$ is set as 1 . Bars indicate the standard error (SE), bars with different letters show significant differences at $p<0.05$.

To examine the role of DvGELP53 in plant-virus interaction, we used a BSMV-mediated virus-induced gene silencing (VIGS) system to knock down the expression of DvGELP53 in D. villosum (Figure 7(aI)); qRT-PCR confirmed the expression of the target gene DvGELP53 was significantly downregulated in the third leaves of BSMV:DvGELP53-inoculated plants compared with that in the BSMV: $\gamma$ control (Figure 7d). This indicated DvGELP53 was silenced successfully. To validate the presence of BSMV, the $\beta-B$ of BSMV in the inoculated leaf (the third leaf) and the upper systemic leaf (the fourth leaf) were detected. We detected $\beta-B$ in the third leaves from both the BSMV: $\gamma$ - and BSMV:DvGELP53-inoculated plants. However, we detected $\beta-B$ only in the upper systemic leaves (the fourth leaves) of the plants inoculated with BSMV: $\gamma$ but not with BSMV:DvGELP53 (Figure 7e). We suspect the knockdown of DvGELP53 blocked the movement of BSMV from the third leaf (inoculated leaf) to the fourth leaf (systemic leaf). We further compared the phenotype brought by BSMV infection on leaves of the plants inoculated with BSMV: $\gamma$ (control) and BSMV:DVGELP53. At 10 dai of BSMV, the chlorotic symptom was observed on the third leaves (inoculated leaf) of the plants inoculated with either BSMV: $\gamma$ or BSMV:DvGELP53, 
with the symptom more pronounced in case of BSMV:DVGELP53 (Figure 7(aI)). At 20 dai, obvious chlorosis was observed on more upper leaves (the non-inoculated fourth and fifth leaves) in the BSMV: $\gamma$ control, while chlorosis was restricted and only observed in the inoculated leaf (the third leaf) in case of BSMV:DVGELP53 (Figure 7(bI)). At 30 dai, the BSMV: $\gamma$ plant was completely BSMV-infected and lethal while the BSMV:DvGELP53 plant had no obvious chlorosis (Figure 7(cI)). False-color images of $Y$ (II) further confirmed the above difference between BSMV: $\gamma$ (control) and BSMV:DVGELP53 (Figure 7(aII-cII)). These results indicated that knockdown of DvGELP53 inhibited the movement of BSMV from inoculated leaves to non-inoculated upper leaves in D. villosum.

(a)

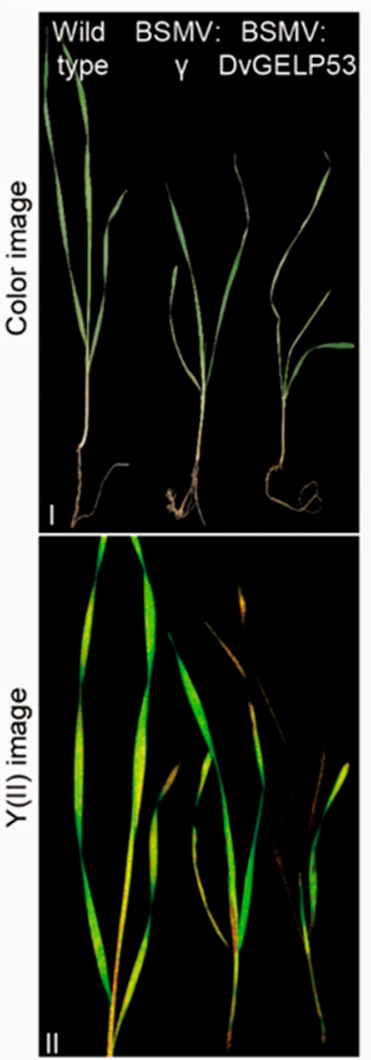

10 dai (b)

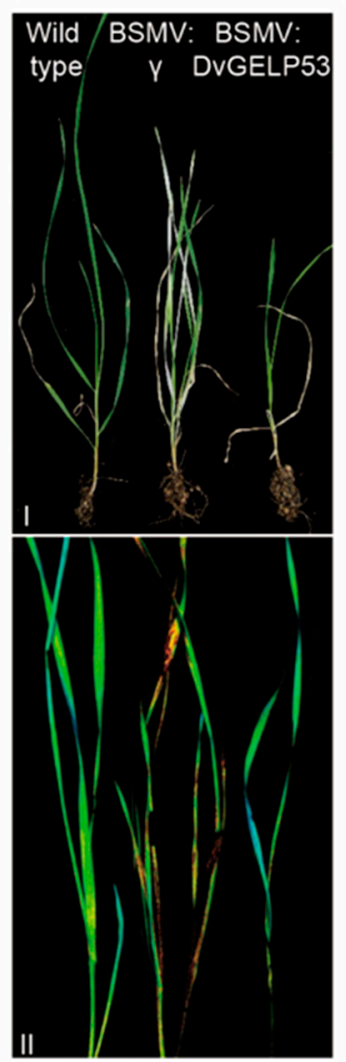

20 dai (c)

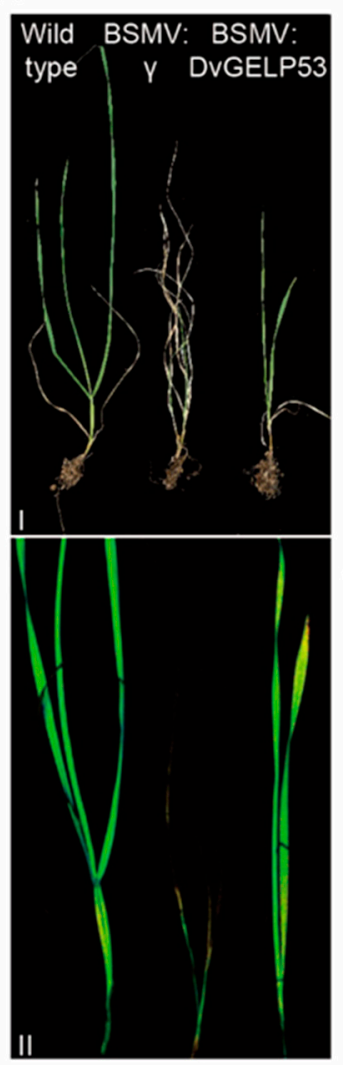

(d)

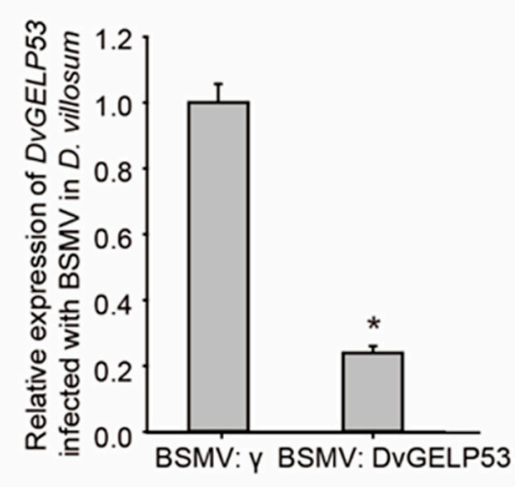

(e)

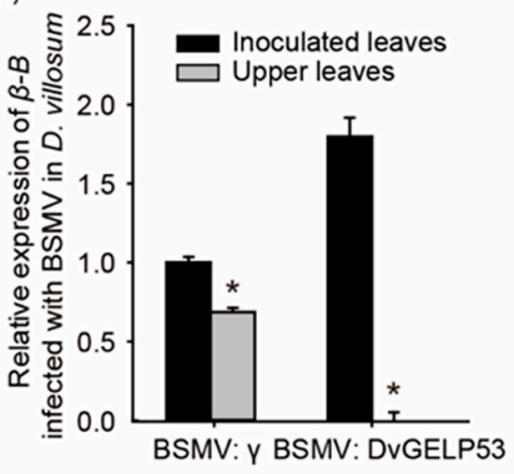

Figure 7. Functional analysis of DvGELP53 by virus-induced gene silencing (VIGS). D. villosum leaves of the seedlings inoculated with BSMV: $\gamma$ or BSMV:DvGELP53 at 10 days after inoculation (dai) (a), 20 dai (b) and 30 dai (c). Successful virus infection in D. villosum was verified by detecting the chlorotic mosaic phenotype on the leaves; (I) and (II) represent visual observation and false-color images of Y(II) measurements at different inoculation times, respectively. Wild type and BSMV: $\gamma$ were control. (d) Expression levels of DvGELP53 in the BSMV: $\gamma$ and BSMV:DvGELP53 plants. The BSMV: $\gamma$ is set to 1. (e) Expression levels of $\beta-B$ (from the BSMV genome) in inoculated leaves and upper leaves of D. villosum at 20 dai. Each point represents the mean of three replicates. Bars indicate the standard error (SE), and * show significant differences at $p<0.05$.

\subsection{Preliminary Study of the Mechanism of DvGELP53 in Regulating Long-Distance BSMV Movement in D. villosum}

To further investigate the function of DvGELP53 in the regulation of virus movement in plants, genome-wide gene expression patterns were compared between BSMV: $\gamma$ and BSMV:DvGELP53 using the third leaves at seven dai of virus. At seven dai, the two types of plants had obvious phenotypic difference, while the third leaves of the BSMV:DvGELP53 plants had not withered yet. A total of 7655 differentially expressed genes (DEGs) with at least a twofold change $(p<0.001)$ were identified in case of BSMV:DvGELP53, in which 3942 
were upregulated and 3713 were downregulated genes. The Kyoto Encyclopedia of Genes and Genomes (KEGG) analysis showed that the DEGs were significantly enriched in terms of plant growth and development, such as "metabolic pathways", "biosynthesis of secondary metabolites", "carbon metabolism", "carbon fixation in photosynthetic organisms", "porphyrin and chlorophyll metabolism" and "photosynthesis" (Figure 8a). Only three enriched terms had more upregulated than downregulated genes (i.e., ko03008). The remaining 17 terms had more downregulated than upregulated genes. Among the 40 DEGs in the photosynthesis pathway (ko00195), seven genes were upregulated and 43 were downregulated, and the expression changes are shown in the heatmap (Figure 8a,b).

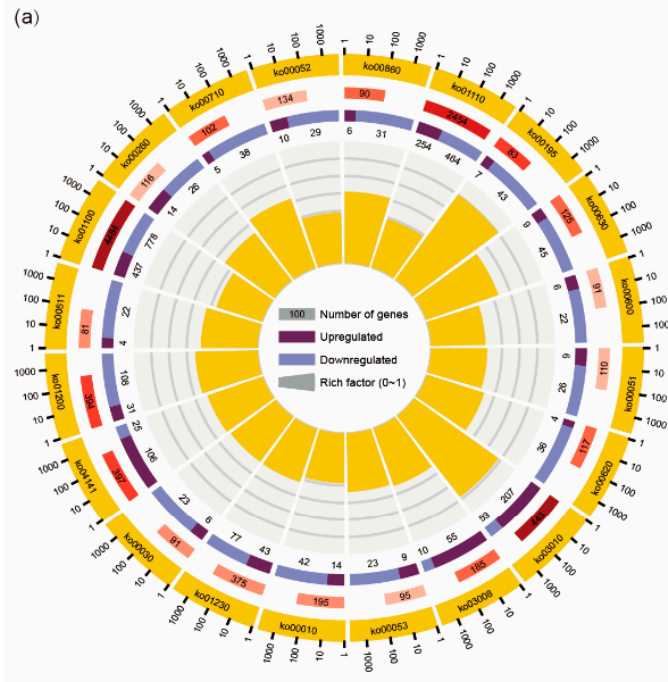

(c)

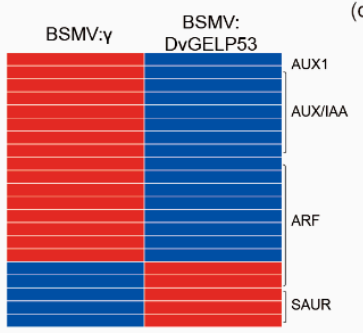

(d)

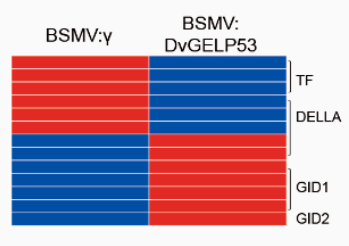

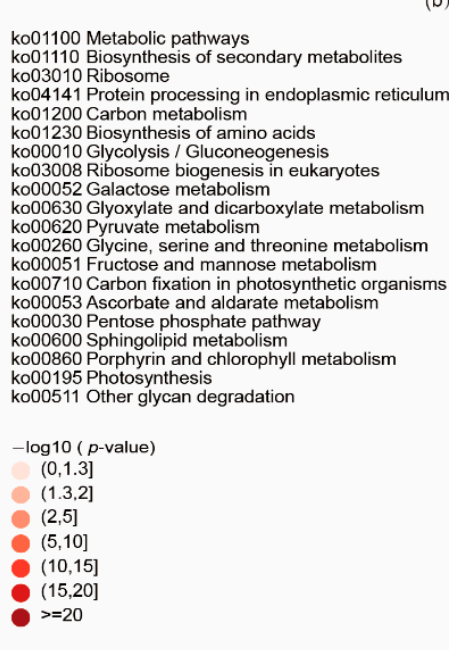

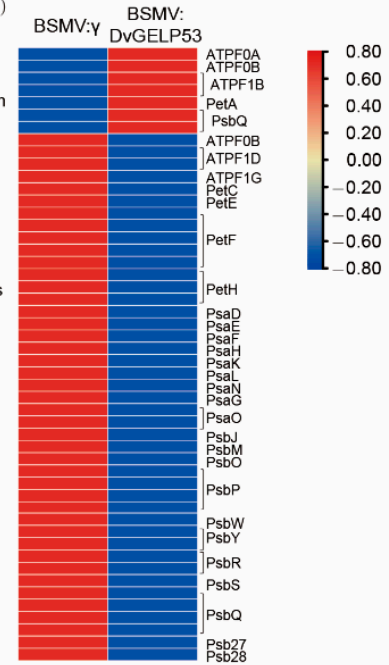

(f)

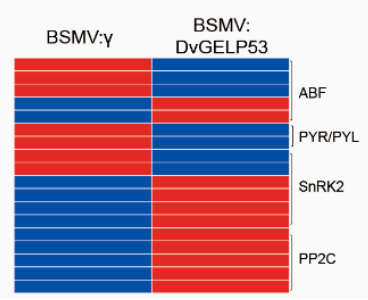

Figure 8. Transcriptome analysis of BSMV: $\gamma$ and BSMV:DvGELP53. (a) KEGG pathway analysis of BSMV: $\gamma$ and BSMV:DvGELP53 for the third leaves inoculated with virus. The circular chart represents distinct KEGG pathways of differentially expressed genes (DEGs). The graph is divided into four circles from the outside to the inside. The first circle represents the terms of enrichment and the outside of the circle is the coordinate ruler of the number of genes. The second circle represents the number of background genes in the category and the $p$-value. The length of the bar represents the number of genes and the shade of red represents the size of the $p$-value. The third circle represents the ratio of the number of upregulated and downregulated genes, dark purple and light purple represent upregulated and downregulated genes, respectively, and the number of genes is shown below. The fourth circle represents the rich factor value of each category, and each box in the background represents 0.1. Heatmap of photosynthesis (b), IAA (c), GA (d), SA (e) and ABA (f) pathway DEGs in case of BSMV: $\gamma$ and BSMV:DvGELP53. The expression signal of each gene is based on the Z-score normalization value.

The Gene Ontology (GO) analysis showed that the DEGs were also significantly enriched in plant growth and development, such as "translation", "organonitrogen compound biosynthetic process", "photosynthesis", "electron transport chain", "nitrogen cycle metabolic process" and "homeostatic process" (Figure S2). The plant hormone (IAA, GA, $\mathrm{SA}$ and $\mathrm{ABA}$ ) signaling pathway genes were analyzed in the transcriptome data. For the IAA signaling pathway, there were more downregulated genes than upregulated ones. In DvGELP53-silenced D. villosum, AUX1, AUX/IAA and ARF were downregulated and ARF, SAUR were upregulated (Figure $8 \mathrm{c}$ ). For the GA, SA and ABA signaling pathways, there 
were more upregulated genes identified than downregulated genes. $P R-1$ and $P P 2 C$ were both upregulated in DvGELP53-silenced D. villosum (Figure 8d-f). These results showed a large amount of genes related to plant growth and development were rapidly downregulated, and the expression levels of the plant hormone signaling pathways were also changed in DvGELP53-silenced D. villosum, causing chlorosis and wilting of the virus-inoculated leaves, and inhibited the virus movement to other leaves, resulting in the prevention of the virus spreading throughout the plants.

\section{Discussion}

\subsection{DvGELP in D. villosum May Have Been Duplicated during Evolution}

GDSL esterase/lipase proteins (GELP) are a subfamily of lipolytic enzymes and the GELP gene family has been identified in only a few plants, such as model plant Arabidopsis, rice and oil crop soybean. Wheat is an important food crop around the world and no GELP gene family studies have been found on wheat and its related species. In this study, we identified and characterized the GELP gene family in D. villosum. D. villosum is a diploid plant similar to Arabidopsis and rice, and 105 and 114 GELPs were found in Arabidopsis and rice, respectively. However, D. villosum with 193 GELPs is similar to soybean (ancient paleopolyploid) with 194 GELPs [6]. Su et al. found that the GELP genes of soybean are duplicated by collinearity alignment and nonsynonymous/synonymous substitution ratio $(\mathrm{Ka} / \mathrm{Ks})$ analysis. In rice, approximately $47 \%$ of the OsGELP genes are closely arranged on chromosomes, comprising 17 clusters [3]. In the soybean genome, $71 \%$ of the GmGDSL family members occur as WGD (whole-genome duplication)/segmental duplication. In our research, the chromosome location analysis showed DvGELPS were mainly closely distributed at the ends of chromosomes, and we speculated about DvGELP duplication during evolution. On average, $65 \%$ of genes have a duplicate copy in plant genomes, and these duplications may lead to the generation of novel functions, such as the adaptability of plants to environmental stress $[39,40]$. For example, Arabidopsis duplicates have likely accumulated novel environmental responses and novel developmental regulatory patterns $[41,42]$. The duplication of disease resistance $(\mathrm{R})$ genes and prolamin genes in plants is also a common phenomenon, which is closely related to their function [43,44]. Analysis of the GELP gene family in different plants shows that the GELP also features duplication, and this duplication may be related to the biological function of the GELP [3,6].

\subsection{The GELP Gene Family May Regulate Plant Development and Various Stress Responses in D. villosum}

The roles of the GELP in plant growth and development, organ morphogenesis, secondary metabolism and stress resistance have been demonstrated. The GELP gene family analysis of different species shows that the expression of GELP is very different. In Arabidopsis, six AtGELPs are expressed in the reproductive organs (siliques and seeds), five AtGELPS appear specifically expressed in the roots, and 16 genes are exclusively expressed in flowers [4]. Some research showed that the function of the GELP gene in Arabidopsis is closely related to its specific expression, such as that many GELP genes have been confirmed to be involved in the development of pollen, including EXL4, EXL6 and GELP77 [45] in Arabidopsis and OsGELP34 [10,46]. EXL4 is specially expressed in anthers of development flowers [47], which affect lipid composition of the pollen coat, and loss of EXL4 leads to the delay in pollen hydration, which further reduces the competitiveness of pollen when compared with wild-type pollen [10]. EXL6 was upregulated during the early stage of pollen development and knockdown of EXL6 caused pollen cytoplasmic degradation after the tetrad stage $[46,48]$. In rice, most of the OsGELP genes are expressed in various organs (i.e., OsGELP1), and some genes are only expressed in a specific tissue. i.e., OsGELP68 is only expressed in panicles. OsGLIP1 is mainly expressed in the leaf and leaf sheath, and OsGLIP2 is highly expressed in elongating internodes. In soybean, a small portion of GmGELP are expressed constitutionally (e.g., GmGELP22), and large amounts of genes show tissue-specific expression, e.g., GmGELP10 shows preferential expression in 
young leaves, flowers, pods and pod shells. In our study, GELPS from D. villosum showed different expression patterns, for example, 36 and 44 DvGELPs exhibited high transcription levels in the spike and the root, respectively, and DvGELP138 was highly expressed in the root and the bud. Specific tissue expression is directly related to their function.

The expression of GELP is also induced by various hormones and stress. The OsGLIP1 and OsGLIP2 from rice are suppressed by pathogen infection and salicylic acid (SA) treatment and negatively regulate plant resistance to bacterial and fungal pathogens. The GER1 from rice is rapidly induced by early light and jasmonic acid (JA) as a negative regulator of light-triggered biosynthesis and coleoptile elongation [49]. The CaGLIP1 from pepper is induced by SA, ET, MeJA, sodium nitroprusside, methyl viologen, high salt, mannitol-mediated dehydration and wounding [9]. Overexpression of CaGLIP1 can enhance the tolerance of transgenic Arabidopsis to drought and susceptibility to the bacterial pathogen Pseudomonas syringae pv. tomato [9]. In our research, the cis-element of the DvGELP promoter sequence included plant hormones, plant growth, environmental stress and light-responsive elements, and the ratio of each component was different. This reveals that the expression of DvGELP can be induced by various biological processes and stress. DvGELP53 was mainly expressed in the root, and was induced by many biotic and abiotic stresses and plant hormones (i.e., powdery mildew, $\mathrm{NaCl}$ and SA); silencing DvGELP53 in $D$. villosum may inhibit the movement of BSMV. This result shows that DvGELP is involved in the interaction of plants and viruses. It implies that the DELP genes might be involved in plant development processes as well as multiple stress responses in D. villosum.

\subsection{DvGELP53 May Function in Regulating Virus Movement and Can Be a Gene Resource for Virus Disease Resistance}

After the virus infects the plant, the systemic infection of plants develops through virus's cell-to-cell movement and long-distance movement [20]. At present, genes related to virus movement have been found in viruses and plants. The movement proteins (MP) from SBWMV, CI from WYMV, P3N-PIPO from TuMV (Turnip mosaic virus) were all proved to participate in the movement of viruses in plants. Previous studies showed that viruses mainly move through plasmodesmata (PD) in plants; the PD is essential for systemic infection in plants by viruses. CI mutations that disrupt virus cell-to-cell movement compromise PD localization capacity [24]. Few genes are involved in virus movement found in plants, and they are mainly found in model plants, e.g., Arabidopsis and $N$. benthamiana. NbHIPP26 from $N$. benthamiana is mainly expressed in root tissues and interact with TGB1 (from PMTV) to participate in the long-distance movement of the PMTV. In NbHIPP26-silenced plants, PMTV cannot move to the leaves that are not inoculated with the virus [27]. NbRPL1 (ribosomal protein large subunit 1) interacts with $\mathrm{NIb}$ (mosaic virus (TVBMV) nuclear inclusion protein) in the chloroplasts, enhancing TVBMV infection. After inoculating TVBMV-GFP in NbRPL1-silenced N. benthamiana plants, the green fluorescence and TVBMV CP cannot be detected in the systemic leaves of the NbRPL1-silenced plants, only in control plants [50]. The auxin/indole acetic acid (Aux/IAA) transcriptional regulators IAA18, IAA26 and IAA27 interact with the tobacco mosaic virus (TMV) 126/183-kDa replicase [51]; a study showed that TMV infection inhibits the nuclear localization of the Aux/IAA proteins, which correlates with enhanced TMV movement and spread in the phloem of older leaves [52]. Wheat is the second most important cereal crop in the world, and soil-borne bymoviruses cause yield losses in wheat as a group of agronomically important pathogens [53]. The study showed that the TaLIP (light-induced protein) interacts with the WYMV nuclear inclusion b protein (NIb); the expression of TaLIP was decreased by WYMV infection, and knockdown of TaLIP compromised wheat resistance to WYMV [54]. In our research, DvGELP53 was cloned from the $D$. villosum relative of wheat, which is highly expressed in roots, similarly to NbHIPP26. Subcellular location shows that DvGELP53 is mainly located in the nucleus and the plasma membrane. The nucleus is shown to play a role in the long-distance movement of some plant viruses [55]. In DvDELP53- silenced plants, the virus RNA ( $\beta$-B) cannot be detected in uninoculated leaves, indicating that the long-distance movement of the virus is inhibited. 
The chloroplasts play an important role in plant-virus interaction, and chloroplast proteins were proved to be involved in several viral infection processes [50]. Chloroplast proteins such as glyceraldehyde 3-phosphate dehydrogenase subunit A (NbGAPDH-A) [56] and chloroplast phosphoglycerate kinase (chl-PGK) [57] are both proven to be involved in virus replication and movement. In our study, transcriptome analysis results showed that many DEGs associated with photosynthesis were mostly downregulated in DvGELP53-silenced plants, and most of these genes play a role in chloroplasts. Therefore, we speculate that DvDELP53 may affect the long-distance movement of BSMV by regulating the expression of certain genes in the chloroplasts. SA and ABA may be related to the movement of plant viruses as exemplified in several studies [28]. In N. tabacum plants, the plum pox virus (PPV) replicates and moves from cell to cell, but does not spread in inoculated leaves. However, PPV was able to move systematically in transgenic tobacco overexpressing SA-degrading enzymes [58]. In Arabidopsis, SA accumulates in cpr1 and cpr5 mutants due to the absence of negative regulators of the SA metabolic pathway, and the long-distance movement of CaMV is blocked in these mutants [59]. In wheat, TaLIP positively regulates the resistance of wheat to WYMV [54]. The promoter sequence analysis showed that there were nine copies of the ABA-responsive elements in the promoter, and the expression level of TaLIP was induced by exogenous SA [54]. The transcription level of the ABA signaling pathway genes TaABI5, TaABI8, TaPYL1, and TaPYL3 were suppressed in TaLIP-silenced wheat [54]. In this study, the IAA, GA, SA and ABA signaling pathway genes were induced or suppressed in DvGELP53-silenced D. villosum, indicating that DvGELP53 may regulate the long-distance movement of viruses through hormone signals. Taken together, our work revealed that DvGELP53 inhibits long-distance BSMV movement, possibly through the hormone signals pathway. The mechanism of DvGELP53 participation in the virus movement requires further research.

\section{Materials and Methods}

\subsection{Plant Materials}

D. villosum (genome VV, accession No. 91C43) from the Cambridge Botanical Garden, Cambridge, UK, was used for gene cloning and expression analysis. Powdery mildew susceptible variety Sumai 3 was used for propagation of fresh spores of powdery mildew isolate E26. N. benthamiana (NC89) plants were used for subcellular localization analysis. The materials were grown in a greenhouse, and the growth conditions were as follows: $14 / 10 \mathrm{~h}$ day/night cycle, $24 / 20^{\circ} \mathrm{C}$ day/night temperature, 8000 lux light intensity and $70 \%$ relative humidity.

\subsection{Identification of the DvGELP Genes in D. villosum}

The identification of the DvGELP gene family in D. villosum was performed according to Zhang et al. (2020) with minor modifications [60]. The GDSL lipase protein in the annotated protein database of $D$. villosum (data not shown) was searched and entries containing gene ID and protein sequences were obtained. A conserved domains (CD) search (https://www.ncbi.nlm.nih.gov /Structure/cdd/wrpsb.cgi (accessed on 15 February 2021)) was performed to identify the protein sequences that contain the GDSL-conserved domain (PF00657). After validation, all the candidate genes encoding the GDSL domain were identified in the D. villosum genome.

\subsection{Phylogenetic Analysis of the DvGELP Gene Family}

Phylogenetic analysis was performed as described by Lai et al. (2017) with the following modifications [4]: multiple sequence alignment was conducted using ClustalW, which was integrated in MEGA X; the neighbor-joining analysis was performed in MEGA $\mathrm{X}$ using a p-distance parameter with 1000 bootstrap replications.

Chromosomal location of the predicted DvGELP genes from D. villosum was obtained by blasting to the genomic sequence using the cDNA sequences as a query. Then, their locations were drawn onto the physical map of each chromosome by using Tbtools [61]. 
The gene structure and intron insertion sites of the DvGELP genes were obtained from the D. villosum database (data not shown), and the domains of the DvGELPs were predicted by CD search (https://www.ncbi.nlm.nih.gov/Structure/cdd/wrpsb.cgi (accessed on 24 February 2021)). The corresponding evolutionary trees were constructed using MEGA $X$ as described above. The formation of the protein structure was constructed using Tbtools [61].

\subsection{Subcellular Localization}

The subcellular localization of DvGELP53 was performed according to Zhang et al. (2020) with some modifications [60]. The CDS of DvGELP53 were cloned into vector pCambia1305-GFP to produce the fusion expression construct 1305-GFP:DvGELP53. The plasma membrane marker construct (mCherry-SYP122) was provided by Prof. Yiqun Bao. The 1305-GFP:DvGELP53 fusion construct and mCherry-SYP122 were transformed into N. benthamiana epidermal cells by Agrobacterium tumefaciens (strain GV3101) incubated in darkness at $22{ }^{\circ} \mathrm{C}$ for $48-60 \mathrm{~h}$. The fluorescence signals were observed under confocal microscopy (LSM780, Zeiss, Oberkochen, Germany).

\subsection{Transcription Abundance Analysis}

Plant treatments were performed as described by Zhao et al. (2018) and Zhang et al. (2020b) with modifications $[60,62]$. The seedlings of D. villosum were grown in a liquid or soil until the three-leaf stage. For testing the transcript levels of DvGELP53 in different tissues of $D$. villosum, the roots, stems, leaves and immature spikes were sampled at $20 \mathrm{~d}$ after flowering. For the heat, cold and drought treatment, the plants were transferred to $42{ }^{\circ} \mathrm{C}$ and $4{ }^{\circ} \mathrm{C}$ or dipped into $20 \%$ PEG 6000, and the leaves were sampled at 0 , $1,2,4,8,12,24$ and $48 \mathrm{~h}$ after treatment. For powdery mildew treatment, the plant was inoculated with pathogen isolate E26, and the leaf tissues were sampled at 0, 2, 6, 12, 24, 36, 48 and $72 \mathrm{~h}$ after inoculation. For chitin, flg22, phytohormones and $\mathrm{H}_{2} \mathrm{O}_{2}$ treatments, the plants were sprayed with $100 \mu \mathrm{g} / \mathrm{mL}$ insoluble chitin, $100 \mu \mathrm{g} / \mathrm{mL}$ flg22, $5 \mathrm{Mm} \mathrm{SA}, 0.2 \mathrm{mM}$ $\mathrm{ABA}, 7 \mathrm{mM} \mathrm{H}_{2} \mathrm{O}_{2}$ and $0.1 \mathrm{mM} \mathrm{ET}$, respectively, and all the leaf tissues were collected at 0 , $1,2,4,8,12,24$ and $48 \mathrm{~h}$ after spraying. For the $\mathrm{NaCl}$ and $\mathrm{Cd}$ treatments, the plants were transferred to $1 / 2$ Murashige and Skoog (MS) medium with $1 \mathrm{mM} \mathrm{CdCl} 2$ or $100 \mathrm{mM} \mathrm{NaCl}$ and all the leaf tissues were collected at $0,1,2,4,8,12,24$ and $48 \mathrm{~h}$ after treatment. All of the samples were rapidly frozen in liquid nitrogen, then stored in an ultra-freezer $\left(-80{ }^{\circ} \mathrm{C}\right)$ until use.

Total RNA was extracted using the TRIzol reagent according to the manufacturer's protocol (Invitrogen). Total RNA $(2 \mu \mathrm{g})$ per sample was used to synthesize the first-strand cDNA using an RNA PCR Kit (TaKaRa). Specific primers for DvGELP53 were used for qRT-PCR (Table S2). The tubulin gene was used as the internal control for normalization; qRT-PCR was performed with AceQ SYBR Green (Vazyme) using a Louts PCR 480 sequence detection system. The relative value of gene expression was derived by $2^{-\triangle \triangle \mathrm{CT}}$ [63].

\subsection{Virus-Induced Gene Silencing (VIGS)}

A partial DvGELP53 sequence was amplified by primer pairs (Table S2), and the resulting fragment (174 bp) was reversely inserted into the vector BSMV: $\gamma$ to generate the recombinant vector BSMV:DvGELP53.

VIGS was performed as described by Wang et al. (2010) [64] with modifications. Recombinant RNA $\gamma$ cDNA clones were in vitro transcribed to obtain the RNA $\gamma$ and RNA $\gamma:$ DvGELP53 transcripts. The methods for in vitro transcription and BSMV recombinant virus inoculation were described by Zhou et al. (2007) [65]. After inoculation, photobleaching on plants was checked at regular intervals. The normal image and the photochemical utilization (Y(II)) of BSMV: $\gamma$ and BSMV:DvGELP53 image were detected at 10, 20 and 30 days after inoculation using a camera and Dual-PAM-100 according to Escher et al. (2006) [66]. 


\subsection{Transcriptome Analysis}

The $D$. villosum plants were grown in field and the root, leaf, node, bud, stem, spike and grain were sampled at $20 \mathrm{~d}$ after flowering. The virus with BSMV:DVGELP53-inoculated D. villosum was collected at 7 days after virus inoculation, and the virus with BSMV: $\gamma$ inoculated D. villosum was used as mock control. Each sample had three biological replicates. All of the samples were immediately frozen in liquid nitrogen and stored at $-80^{\circ} \mathrm{C}$. Total RNA was extracted using the TRIzol reagent (Invitrogen, Waltham, MA, USA) according to the manufacturer's instructions. RNA concentration was determined using a NanoDrop spectrophotometer and 1.2\% agarose gel electrophoresis. RNA-Seq was performed using a BGISEQ-500 sequencing platform by BGI Company, Shenzhen, China. The raw reads were cleaned by removing the adapter and low-quality sequences (percentage of low-quality bases with a quality value $\leq 10$ in more than $20 \%$ of a read). The gene expression levels were calculated by RSEM (v1.2.8, default). The DEGs (differentially expressed genes) were detected by DEGseq (fold change $\geq 2$ and adjusted $p$-value $\leq 0.001$ ). The GO enrichment analysis and KEGG enrichment analysis of DEGs were performed using a free online platform for data analysis, the OmicShare tools (http:/ / www.omicshare.com/tools (accessed on 5 April 2021)). Log2 FPKM values after Z-score normalization were used for the heatmap of DEGs expression.

\section{Conclusions}

This study identified 193 GELP genes from D. villosum. Evolutionary and protein structure analyses showed that DvGELP could be classified into 11 groups, and closer $D v G E L P$ genes in the phylogenetic tree have similar gene structures. The cis-elements in the primer sequence and tissue-specific expression analysis showed that GELP genes may be involved in multiple pathways of plant development. DvGELP53 was upregulated in the leaves of $D$. villosum in response to multiple biotic and abiotic stresses. Transient silencing of DvGELP53 inhibits long-distance BSMV movement. Our study systematically analyzed the distribution and evolution of the GELP gene family in D. villosum and demonstrated the important role of DvGELP53 in plant-virus interaction.

Supplementary Materials: The following are available online at https:/ / www.mdpi.com/article/10 .3390/ijms222212317/s1.

Author Contributions: Data curation, H.Z., X.Z., H.W. and J.X.; Formal analysis, H.Z., H.W., J.X. and X.W.; Funding acquisition, J.X. and X.W.; Investigation, X.Z., J.Z., L.S., J.X. and X.W.; Methodology, H.Z., J.Z., L.S. and J.X.; Resources, J.X. and X.W.; Software, X.Z. and J.X.; Validation, X.Z., J.Z., L.S. and H.W.; Visualization, H.Z. and X.Z.; Writing-original draft preparation, H.Z., X.Z. and J.X.; Writing-review and editing, H.Z., Y.Z., J.X. and X.W. All authors have read and agreed to the published version of the manuscript.

Funding: This research was funded by grants from the National Natural Science Foundation of China (Major Program) (No. 91935304), the Zhejiang Major Scientific and Technological Project of Agricultural (Upland crop) Breeding (No. 2021C02064-6), the International Cooperation and Exchange of the National Natural Science Foundation of China (No. 31661143005), the National Natural Science Foundation of China (No. 31971943), the Program of Introducing Talents of Dis-cipline to Universities (No. B08025), the Jiangsu Agricultural Technology System (JATS) (No. JATS [2020]411), the Key Research and Development Major Project of the Ningxia Autonomous Region (No. 2019BBF02022-04) and the National Key Research and Development Program of China (No. 2020YFE0202900).

Institutional Review Board Statement: Not applicable.

Informed Consent Statement: Not applicable.

Data Availability Statement: Not applicable.

Conflicts of Interest: The authors declare no conflict of interest. 


\section{References}

1. Akoh, C.C.; Lee, G.C.; Liaw, Y.C.; Huang, T.H.; Shaw, J.F. GDSL family of serine esterases/lipases. Prog. Lipid Res. 2004, 43, 534-552. [CrossRef] [PubMed]

2. Upton, C.; Buckley, J.T. A new family of lipolytic enzymes? Trends Biochem. Sci. 1995, 20, 178-179. [CrossRef]

3. Chepyshko, H.; Lai, C.P.; Huang, L.M.; Liu, J.H.; Shaw, J.F. Multifunctionality and diversity of GDSL esterase/lipase gene family in rice (Oryza sativa L. japonica) genome: New insights from bioinformatics analysis. BMC Genom. 2012, 13, 309. [CrossRef]

4. Lai, C.P.; Huang, L.M.; Chen, L.O.; Chan, M.T.; Shaw, J.F. Genome-wide analysis of GDSL-type esterases/lipases in Arabidopsis. Plant Mol. Biol. 2017, 95, 181-197. [CrossRef]

5. Volokita, M.; Rosilio-Brami, T.; Rivkin, N.; Zik, M. Combining comparative sequence and genomic data to ascertain phylogenetic relationships and explore the evolution of the large GDSL-lipase family in land plants. Mol. Biol. Evol. 2011, 28, 551-565. [CrossRef] [PubMed]

6. Su, H.G.; Zhang, X.H.; Wang, T.T.; Wei, W.L.; Wang, Y.X.; Chen, J.; Zhou, Y.B.; Chen, M.; Ma, Y.Z.; Xu, Z.S.; et al. Genome-Wide Identification, Evolution, and Expression of GDSL-Type Esterase/Lipase Gene Family in Soybean. Front. Plant Sci. 2020, 11, 726. [CrossRef]

7. Naranjo, M.A.; Forment, J.; Roldan, M.; Serrano, R.; Vicente, O. Overexpression of Arabidopsis thaliana LTL1, a salt-induced gene encoding a GDSL-motif lipase, increases salt tolerance in yeast and transgenic plants. Plant Cell Environ. 2006, 29, 1890-1900. [CrossRef] [PubMed]

8. Gao, M.; Yin, X.; Yang, W.; Lam, S.M.; Tong, X.; Liu, J.; Wang, X.; Li, Q.; Shui, G.; He, Z. GDSL lipases modulate immunity through lipid homeostasis in rice. PLoS Pathog. 2017, 13, e1006724. [CrossRef] [PubMed]

9. Hong, J.K.; Choi, H.W.; Hwang, I.S.; Kim, D.S.; Kim, N.H.; Choi, D.S.; Kim, Y.J.; Hwang, B.K. Function of a novel GDSL-type pepper lipase gene, CaGLIP1, in disease susceptibility and abiotic stress tolerance. Planta 2008, 227, 539-558. [CrossRef]

10. Updegraff, E.P.; Zhao, F.; Preuss, D. The extracellular lipase EXL4 is required for efficient hydration of Arabidopsis pollen. Sex. Plant Reprod. 2009, 22, 197-204. [CrossRef]

11. An, X.; Dong, Z.; Tian, Y.; Xie, K.; Wu, S.; Zhu, T.; Zhang, D.; Zhou, Y.; Niu, C.; Ma, B.; et al. ZmMs30 Encoding a Novel GDSL Lipase Is Essential for Male Fertility and Valuable for Hybrid Breeding in Maize. Mol. Plant 2019, 12, 343-359. [CrossRef]

12. Zhang, H.; Wang, M.; Li, Y.; Yan, W.; Chang, Z.; Ni, H.; Chen, Z.; Wu, J.; Xu, C.; Deng, X.W.; et al. GDSL esterase/lipases OsGELP34 and OsGELP110/OsGELP115 are essential for rice pollen development. J. Integr. Plant Biol. 2020, 62, $1574-1593$. [CrossRef]

13. Huang, L.M.; Lai, C.P.; Chen, L.O.; Chan, M.T.; Shaw, J.F. Arabidopsis SFAR4 is a novel GDSL-type esterase involved in fatty acid degradation and glucose tolerance. Bot. Stud. 2015, 56, 33. [CrossRef]

14. Zhang, B.; Zhang, L.; Li, F.; Zhang, D.; Liu, X.; Wang, H.; Xu, Z.; Chu, C.; Zhou, Y. Control of secondary cell wall patterning involves xylan deacetylation by a GDSL esterase. Nat. Plants 2017, 3, 17017. [CrossRef]

15. Clauss, K.; Baumert, A.; Nimtz, M.; Milkowski, C.; Strack, D. Role of a GDSL lipase-like protein as sinapine esterase in Brassicaceae. Plant J. Cell Mol. Biol. 2008, 53, 802-813. [CrossRef]

16. Kim, H.G.; Kwon, S.J.; Jang, Y.J.; Chung, J.H.; Nam, M.H.; Park, O.K. GDSL lipase 1 regulates ethylene signaling and ethyleneassociated systemic immunity in Arabidopsis. FEBS Lett. 2014, 588, 1652-1658. [CrossRef]

17. Kim, H.G.; Kwon, S.J.; Jang, Y.J.; Nam, M.H.; Chung, J.H.; Na, Y.C.; Guo, H.; Park, O.K. GDSL LIPASE1 modulates plant immunity through feedback regulation of ethylene signaling. Plant Physiol. 2013, 163, 1776-1791. [CrossRef] [PubMed]

18. Lee, D.S.; Kim, B.K.; Kwon, S.J.; Jin, H.C.; Park, O.K. Arabidopsis GDSL lipase 2 plays a role in pathogen defense via negative regulation of auxin signaling. Biochem. Biophys. Res. Commun. 2009, 379, 1038-1042. [CrossRef] [PubMed]

19. Jiang, C.; Kan, J.; Ordon, F.; Perovic, D.; Yang, P. Bymovirus-induced yellow mosaic diseases in barley and wheat: Viruses, genetic resistances and functional aspects. Theor. Appl. Genet. 2020, 133, 1623-1640. [CrossRef]

20. Gilbertson, R.L.; Lucas, W.J. How do viruses traffic on the 'vascular highway'? Trends Plant Sci. 1996, 1, 250-251. [CrossRef]

21. Ohki, T.; Sasaya, T.; Maoka, T. Cylindrical Inclusion Protein of Wheat Yellow Mosaic Virus Is Involved in Differential Infection of Wheat Cultivars. Phytopathology 2019, 109, 1475-1480. [CrossRef] [PubMed]

22. Carrington, J.C.; Jensen, P.E.; Schaad, M.C. Genetic evidence for an essential role for potyvirus CI protein in cell-to-cell movement. Plant J. Cell Mol. Biol. 1998, 14, 393-400. [CrossRef]

23. Zhang, C.; Machray, G.C.; Cruz, S.S.; Wilson, T.M.A. Soil-Borne Wheat Mosaic Virus (SBWMV) $37^{\circ}$ kDa Protein Rescues Cellto-Cell and Long-Distance Movement of an Immobile Tobacco Mosaic Virus Mutant in Nicotiana benthamiana, a Non-Host of SBWMV. J. Phytopathol. 2010, 153, 5-10. [CrossRef]

24. Wei, T.; Zhang, C.; Hong, J.; Xiong, R.; Kasschau, K.D.; Zhou, X.; Carrington, J.C.; Wang, A.; Manchester, M. Formation of Complexes at Plasmodesmata for Potyvirus Intercellular Movement Is Mediated by the Viral Protein P3N-PIPO. PLoS Pathog. 2010, 6, e1000962. [CrossRef]

25. Wang, A.; Krishnaswamy, S. Eukaryotic translation initiation factor 4E-mediated recessive resistance to plant viruses and its utility in crop improvement. Mol. Plant Pathol. 2012, 13, 795-803. [CrossRef] [PubMed]

26. Jiang, J.; Laliberte, J.F. The genome-linked protein VPg of plant viruses-a protein with many partners. Curr. Opin. Virol. 2011, 1, 347-354. [CrossRef] [PubMed] 
27. Cowan, G.H.; Roberts, A.G.; Jones, S.; Kumar, P.; Kalyandurg, P.B.; Gil, J.F.; Savenkov, E.I.; Hemsley, P.A.; Torrance, L. Potato Mop-Top Virus Co-Opts the Stress Sensor HIPP26 for Long-Distance Movement. Plant Physiol. 2018, 176, 2052-2070. [CrossRef] [PubMed]

28. Hipper, C.; Brault, V.; Ziegler-Graff, V.; Revers, F. Viral and cellular factors involved in Phloem transport of plant viruses. Front. Plant Sci. 2013, 4, 154. [CrossRef] [PubMed]

29. Dunoyer, P.; Thomas, C.; Harrison, S.; Revers, F.; Maule, A. A cysteine-rich plant protein potentiates potyvirus movement through an interaction with the virus genome-linked protein VPg. J. Virol. 2004, 78, 2301-2309. [CrossRef]

30. The International Wheat Genome Sequencing Consortium (IWGSC); Appels, R.; Eversole, K.; Feuillet, C.; Keller, B.; Rogers, J.; Stein, N.; Pozniak, C.J.; Choulet, F.; Distelfeld, A.; et al. Shifting the limits in wheat research and breeding using a fully annotated reference genome. Science 2018, 361, eaar7191.

31. Mren, M. The cyst nematode Heteroderalatipons Franklin, 1969 (Nemata: Heteroderidae): Hatching behavior and development on wheat in arid and semiarid regions in Turkey. Turk. J. Agric. For. 2020, 44, 331-338.

32. Avatli, Y. The effects of wheatgrass length on antioxidant activity and total phenolic content in wheatgrass (Triticum spp.). Turk. J. Agric. For. 2020, 44, 271-277.

33. Holubec, V.; Dvořáček, V.; Svobodová Leišová, L.; Ercisli, S. Morphological, Genetic and Biochemical Evaluation of Dasypyrum villosum (L.) P. Candargy in the Gene Bank Collection. Agronomy 2021, 11, 1316. [CrossRef]

34. He, H.; Zhu, S.; Zhao, R.; Jiang, Z.; Ji, Y.; Ji, J.; Qiu, D.; Li, H.; Bie, T. Pm21, Encoding a Typical CC-NBS-LRR Protein, Confers Broad-Spectrum Resistance to Wheat Powdery Mildew Disease. Mol. Plant 2018, 11, 879-882. [CrossRef]

35. Xing, L.; Hu, P.; Liu, J.; Witek, K.; Zhou, S.; Xu, J.; Zhou, W.; Gao, L.; Huang, Z.; Zhang, R.; et al. Pm21 from Haynaldia villosa Encodes a CC-NBS-LRR Protein Conferring Powdery Mildew Resistance in Wheat. Mol. Plant 2018, 11, 874-878. [CrossRef] [PubMed]

36. Yildirim, A.; Jones, S.S.; Murray, T.D.; Line, R.F. Evaluation of Dasypyrum villosum Populations for Resistance to Cereal Eyespot and Stripe Rust Pathogens. Plant Dis. 2000, 84, 40-44. [CrossRef]

37. Zhao, R.; Wang, H.; Xiao, J.; Bie, T.; Cheng, S.; Jia, Q.; Yuan, C.; Zhang, R.; Cao, A.; Chen, P.; et al. Induction of 4VS chromosome recombinants using the $\mathrm{CS}$ ph1b mutant and mapping of the wheat yellow mosaic virus resistance gene from Haynaldia villosa. Theor. Appl. Genet. 2013, 126, 2921-2930. [CrossRef] [PubMed]

38. Zhong, G.Y.; Dvořák, J. Evidence for common genetic mechanisms controlling the tolerance of sudden salt stress in the tribe Triticeae. Plant Breed. 2010, 114, 297-302. [CrossRef]

39. Panchy, N.; Lehti-Shiu, M.; Shiu, S.H. Evolution of Gene Duplication in Plants. Plant Physiol. 2016, 171, 2294-2316. [CrossRef] [PubMed]

40. Magadum, S.; Banerjee, U.; Murugan, P.; Gangapur, D.; Ravikesavan, R. Gene duplication as a major force in evolution. J. Genet. 2013, 92, 155-161. [CrossRef]

41. Zou, C.; Lehti-Shiu, M.D.; Thomashow, M.; Shiu, S.H. Evolution of stress-regulated gene expression in duplicate genes of Arabidopsis thaliana. PLoS Genet. 2009, 5, e1000581. [CrossRef]

42. Shao-Lun, L.; Baute, G.J.; Adams, K.L. Organ and Cell Type-Specific Complementary Expression Patterns and Regulatory Neofunctionalization between Duplicated Genes in Arabidopsis thaliana. Genome Biol. Evol. 2011, 3, 1419-1436.

43. Huo, N.; Zhang, S.; Zhu, T.; Dong, L.; Wang, Y.; Mohr, T.; Hu, T.; Liu, Z.; Dvorak, J.; Luo, M.C.; et al. Gene Duplication and Evolution Dynamics in the Homeologous Regions Harboring Multiple Prolamin and Resistance Gene Families in Hexaploid Wheat. Front. Plant Sci. 2018, 9, 673. [CrossRef] [PubMed]

44. Yu, J.; Ke, T.; Tehrim, S.; Sun, F.; Liao, B.; Hua, W. PTGBase: An integrated database to study tandem duplicated genes in plants. Database J. Biol. Databases Curation 2015, 2015, bav017. [CrossRef]

45. Tsugama, D.; Fujino, K.; Liu, S.; Takano, T. A GDSL-type esterase/lipase gene, GELP77, is necessary for pollen dissociation and fertility in Arabidopsis. Biochem. Biophys. Res. Commun. 2020, 526, 1036-1041. [CrossRef] [PubMed]

46. Dong, X.; Yi, H.; Han, C.T.; Nou, I.S.; Hur, Y. GDSL esterase/lipase genes in Brassica rapa L.: Genome-wide identification and expression analysis. Mol. Genet. Genom. 2016, 291, 531-542. [CrossRef] [PubMed]

47. Zimmermann, P.; Hirsch-Hoffmann, M.; Hennig, L.; Gruissem, W. GENEVESTIGATOR. Arabidopsis microarray database and analysis toolbox. Plant Physiol. 2004, 136, 2621-2632. [CrossRef]

48. Dong, X.; Feng, H.; Xu, M.; Lee, J.; Kim, Y.K.; Lim, Y.P.; Piao, Z.; Park, Y.D.; Ma, H.; Hur, Y. Comprehensive analysis of genic male sterility-related genes in Brassica rapa using a newly developed Br300K oligomeric chip. PLoS ONE 2013, 8, e72178. [CrossRef]

49. Riemann, M.; Gutjahr, C.; Korte, A.; Riemann, M.; Danger, B.; Muramatsu, T.; Bayer, U.; Waller, F.; Furuya, M.; Nick, P. GER1, a GDSL motif-encoding gene from rice is a novel early light- and jasmonate-induced gene. Plant Biol. 2007, 9, 32-40. [CrossRef]

50. Cheng, D.J.; Xu, X.J.; Yan, Z.Y.; Tettey, C.K.; Fang, L.; Yang, G.L.; Geng, C.; Tian, Y.P.; Li, X.D. The chloroplast ribosomal protein large subunit 1 interacts with viral polymerase and promotes virus infection. Plant Physiol. 2021, 187, 174-186. [CrossRef]

51. Padmanabhan, M.S.; Shiferaw, H.; Culver, J.N. The Tobacco mosaic virus replicase protein disrupts the localization and function of interacting Aux/IAA proteins. Mol. Plant-Microbe Interact. MPMI 2006, 19, 864-873. [CrossRef]

52. Collum, T.D.; Padmanabhan, M.S.; Hsieh, Y.C.; Culver, J.N. Tobacco mosaic virus-directed reprogramming of auxin/indole acetic acid protein transcriptional responses enhances virus phloem loading. Proc. Natl. Acad. Sci. USA 2016, 113, E2740-E2749. [CrossRef] 
53. Kanyuka, K.; Ward, E.; Adams, M.J. Polymyxa graminis and the cereal viruses it transmits: A research challenge. Mol. Plant Pathol. 2003, 4, 393-406. [CrossRef] [PubMed]

54. Zhang, T.; Liu, P.; Zhong, K.; Zhang, F.; Xu, M.; He, L.; Jin, P.; Chen, J.; Yang, J. Wheat Yellow Mosaic Virus NIb Interacting with Host Light Induced Protein (LIP) Facilitates Its Infection through Perturbing the Abscisic Acid Pathway in Wheat. Biology 2019, 8, 80. [CrossRef]

55. Taliansky, M.E.; Brown, J.W.; Rajamaki, M.L.; Valkonen, J.P.; Kalinina, N.O. Involvement of the plant nucleolus in virus and viroid infections: Parallels with animal pathosystems. Adv. Virus Res. 2010, 77, 119-158.

56. Kaido, M.; Abe, K.; Mine, A.; Hyodo, K.; Taniguchi, T.; Taniguchi, H.; Mise, K.; Okuno, T. GAPDH-a recruits a plant virus movement protein to cortical virus replication complexes to facilitate viral cell-to-cell movement. PLoS Pathog. 2014, 10, e1004505. [CrossRef]

57. Cheng, S.F.; Huang, Y.P.; Chen, L.H.; Hsu, Y.H.; Tsai, C.H. Chloroplast phosphoglycerate kinase is involved in the targeting of Bamboo mosaic virus to chloroplasts in Nicotiana benthamiana plants. Plant Physiol. 2013, 163, 1598-1608. [CrossRef] [PubMed]

58. Alamillo, J.M.; Saenz, P.; Garcia, J.A. Salicylic acid-mediated and RNA-silencing defense mechanisms cooperate in the restriction of systemic spread of plum pox virus in tobacco. Plant J. Cell Mol. Biol. 2006, 48, 217-227. [CrossRef]

59. Love, A.J.; Laval, V.; Geri, C.; Laird, J.; Tomos, A.D.; Hooks, M.A.; Milner, J.J. Components of Arabidopsis defense- and ethylenesignaling pathways regulate susceptibility to Cauliflower mosaic virus by restricting long-distance movement. Mol. Plant-Microbe Interact. MPMI 2007, 20, 659-670. [CrossRef] [PubMed]

60. Zhang, H.; Zhang, X.; Liu, J.; Niu, Y.; Chen, Y.; Hao, Y.; Zhao, J.; Sun, L.; Wang, H.; Xiao, J.; et al. Characterization of the Heavy-Metal-Associated Isoprenylated Plant Protein (HIPP) Gene Family from Triticeae Species. Int. J. Mol. Sci. 2020, $21,6191$. [CrossRef]

61. Chen, C.; Chen, H.; Zhang, Y.; Thomas, H.R.; Frank, M.H.; He, Y.; Xia, R. TBtools: An Integrative Toolkit Developed for Interactive Analyses of Big Biological Data. Mol. Plant 2020, 13, 1194-1202. [CrossRef] [PubMed]

62. Zhao, J.; Zhang, X.; Wan, W.; Zhang, H.; Liu, J.; Li, M.; Wang, H.; Xiao, J.; Wang, X. Identification and Characterization of the EXO70 Gene Family in Polyploid Wheat and Related Species. Int. J. Mol. Sci. 2019, 20, 60. [CrossRef] [PubMed]

63. Livak, K.J.; Schmittgen, T.D. Analysis of Relative Gene Expression Data Using Real-Time Quantitative PCR and the 2- ${ }^{\Delta C T}$ Method. Methods 2001, 25, 402-408. [CrossRef] [PubMed]

64. Wang, X.; Cao, A.; Yu, C.; Wang, D.; Wang, X.; Chen, P. Establishment of an effective virus induced gene silencing system with BSMV in Haynaldia villosa. Mol. Biol. Rep. 2010, 37, 967-972. [CrossRef]

65. Zhou, H.; Li, S.; Deng, Z.; Wang, X.; Chen, T.; Zhang, J.; Chen, S.; Ling, H.; Zhang, A.; Wang, D.; et al. Molecular analysis of three new receptor-like kinase genes from hexaploid wheat and evidence for their participation in the wheat hypersensitive response to stripe rust fungus infection. Plant J. Cell Mol. Biol. 2007, 52, 420-434. [CrossRef] [PubMed]

66. Escher, B.I.; Quayle, P.; Muller, R.; Schreiber, U.; Mueller, J.F. Passive sampling of herbicides combined with effect analysis in algae using a novel high-throughput phytotoxicity assay (Maxi-Imaging-PAM). J. Environ. Monit. 2006, 8, 456-464. [CrossRef] 